JAMP: Jurnal Adminitrasi dan Manajemen Pendidikan

Volume 4 Nomor 2 Juni 2021, Hal : 107 - 114

Tersedia Online di http://journal2.um.ac.id/index.php/jamp/

ISSN 2615-8574 (online)

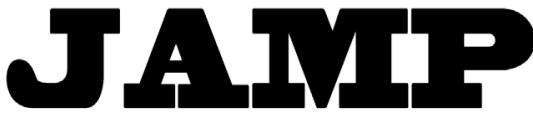

JURNAL ADMINISTRASI DAN MANAJEMEN PENDIDIKAN

\title{
PEMANFAATAN JARINGAN KERJASAMA ANTAR ORGANISASI: SEBUAH PANDANGAN PEMIMPIN WANITA SEKOLAH MENENGAH ATAS
}

\author{
Suryawahyuni Latief ${ }^{1}$ \\ Santi Hendrayani ${ }^{2}$ \\ Puji Lestari ${ }^{3}$ \\ ${ }^{1,2}$ Universitas Nurdin Hamzah Jambi \\ ${ }^{3}$ Pascasarjana UIN STS Jambi \\ E-mail: niniek yuni@yahoo.com
}

\begin{abstract}
This research aims to describe the utilization of a network of partnership between organizations in achieving school goals in the view of female principals at the public and private senior high schools in Jambi City. This research uses a qualitative approach designed with qualitative descriptive approached. The data in this study collected through observations, interviews, and documentation. Data analyzed by using qualitative research data analysis techniques. The study found that the utilization of a network of partnership between organizations in the view of female leaders based on three judged, namely the availability of school resources, the needs of students, and the need for information. Meanwhile, a network of partnership carried out between equal or non-equal school organizations and other institutions that care about education in the form of the use of facilities and sit in students.
\end{abstract}

Keywords: Utilization; networking; partnership; leader's women.

\begin{abstract}
Abstrak: Penelitian ini bertujuan untuk mendeskripsikan pemanfaatan jaringan kerjasama antar organisasi dalam pencapaian tujuan sekolah dalam pandangan kepala sekolah perempuan di tingkat sekolah menengah atas negeri dan swasta di Kota Jambi. Penelitian ini menggunakan pendekatan kualitatif yang didesain dengan rancangan deskriptif kualitatif. Data dalam penelitian ini dikumpulkan melalui observasi, wawancara, dan dokumentasi. Data dianalisis dengan menggunakan teknik analisis data penelitian kualitatif. Berdasarkan hasil penelitian dapat disimpulkan bahwa pemanfaatan jaringan kerjasama antar organisasi dalam pandangan pemimpin perempuan berdasarkan atas tiga pertimbanagan yaitu ketersediaan sumberdaya sekolah, kebutuhan peserta didik, dan kebutuhan informasi. Sedangkan bentuk jaringan kerjasama dilakukan antar organisasi sekolah yang sederajat maupun tidak sederajat dan lembaga lain yang peduli dengan pendidikan berupa penggunaan fasilitas dan sit in peserta didik.
\end{abstract}

Kata Kunci: Pemanfaatan; jaringan kerja; kerjasama; pemimpin perempuan.

Pendidikan merupakan salah satu aspek terpenting dalam meningkatkan kualitas sumberdaya manusia dan menghasilkan individu yang memiliki karakter yang dapat bersaing secara kompetitif baik di tingkat lokal maupun internasional. Fungsi dan tujuan pendidikan nasional menurut Undang-Undang Nomor 20 Tahun 2003 tentang Sistem Pendidikan Nasional Pasal 3 adalah mengembangkan kemampuan dan membentuk watak serta peradaban bangsa yang bermartabat dalam rangka mencerdaskan kehidupan bangsa, bertujuan untuk berkembangnya potensi peserta didik agar menjadi manusia yang beriman dan bertakwa kepada Tuhan Yang Maha Esa, berakhlak mulia, sehat, berilmu, cakap, kreatif, mandiri, dan menjadi warga negara yang demokratis serta bertanggung jawab. 
Upaya pencapaian tujuan pendidikan, maka dibentuklah sekolah sebagai salah satu bentuk organisasi yang bergerak di bidang pendidikan, yang dipimpin oleh seorang kepala sekolah. Salah satu bentuk lembaga pendidikan berdasarkan sistem pendidikan di Indonesia adalah sekolah menengah atas. Menurut undang-undang pendidikan nasional nomor 20 tahun 2003 pasal 18 adalah sekolah menengah atas adalah lanjutan dari pendidikan sekolah menengah pertama. Sekolah menengah atas terdiri atas sekolah menengah atas umum, madrasah aliyah, sekolah menengah kejuruan dan sekolah lain yang memiliki tingkatan yang sama.

Salah satu faktor yang mempengaruhi pencapaian tujuan sekolah adalah pemimpin. Pemimpin merupakan individu yang secara signifikan mendorong, mempengaruhi, mengarahkan, dan melaksanakan tercapainya tujuan organisasi. Higgs (2013) dan Sheikh (2010) menyatakan bahwa pemimpin adalah individu yang memiliki kemampuan memprediksi, mengajak, menyanggupi, mengembangkan, dan menjalankan organisasi dengan kesadaran dan keyakinan serta kesatuan tekad untuk memajukan organisasi melalui kepemimpinannya. Werhane \& Morland (2011) mendefinisikan pemimpin sebagai individu yang mempengaruhi perilaku, pemikiran dan perasaan orang lain.

Pemimpin sebagai individu yang memiliki tanggungjawab dan fungsi dalam pencapaianan tujuan organisasi melalui kepemimpinannya. Kepemimpinan dan gender merupakan salah satu topik kajian yang dilakukan oleh para peneliti sejak dahulu hingga saat ini. Kajian tersebut antara lain berupa gaya kepemimpinan perempuan (Gipson et.all, 2017; Eagly \& Schmidt, 2002), kepemimpinan perempuan dalam politik (Mendelberg \& Karpowitz, 2016, Adler, 1996; Lipman, 1992), dan stereotype pemimpin perempuan (Hoyt \& Murphy, 2016; Gupta \& Bhawe, 2007; Alice \& Mary, 2002 ).

Yulk (2010) mengemukakan bahwa kepemimpinan adalah kosa kata umum yang digunakan dalam segala tingkatan tanpa memberikan definisi yang baru dan berkenaan dengan kekuasaan, kewenangan, manajemen, administrasi dan supervisi. Kepemimpinan berkenaan dengan pemanfaatan setiap kesempatan, penciptaan suatu tujuan dan fokus pada proses pencapaian tujuan (Knowles, 2011). Hal senada terkait kepemimpinan dinyatakan oleh Hicks \& Gullet (1995) bahwa kepemimpinan merupakan pemenuhan tujuan organisasi melalui proses yang dilakukan.

Sekolah sebagai organisasi tempat mengajar dan belajar terdiri atas individu atau sekelompok yang melakukan hubungan kerjasama yang bersifat kerjasama inter organisasi dan kerjasama antar organisasi. Kerjasama inter organisasi adalah kerjasama yang melibatkan komponen dalam sekolah yaitu kepala sekolah, tenaga pendidik dan kependidikan, peserta didik, dan orang tua peserta didik. Sumarsono, et. al. (2016) menyatakan bahwa penyelenggaraan pendidikan merupakan tanggung jawab bersama antara pemerintah, orang tua, dan masyarakat. Ketiga lingkungan tersebut, sesuai dengan fungsi dan peran masing-masing, harus berupaya agar mutu pendidikan terselenggara secara optimal. Kerjasama antar organisasi merupakan kerjasama yang dilakukan dengan pihak diluar sekolah seperti sekolah lain, masyarakat sekitar sekolah, perusahaan dan lain sebagainya.

Kerjasama menurut Purwadarminta dalam Suarno \& Miswan (2014) adalah suatu kegiatan atau tindakan yang saling membantu dan dilakukan secara bersama-sama. Sehingga, kerjasama inter dan atau antar organisasi memiliki arti adanya kegiatan inter dan atau antar organisasi yang dilakukan secara bersama-sama dalam upaya pencapaian tujuan.

Jaringan kerjasama antar organisasi dikenal dengan istilah partnership atau kemitraan. Tugas seorang pemimpin selain melakukan jaringan kerjasama dalam organisasi, juga melakukan jaringan kerjasama dengan pihak lain. Tujuan kerjasama merupakan upaya pemimpin menumbuhkan, mengembangkan dan menata tercapainya tujuan organisasi. Jaringan kerjasama memiliki makna persekutuan anatara dua pihak atau lebih yang saling membantu dalam mencapai tujuan yang telah ditetapkan dalam suatu organisasi. Sedangkan Suarno dan Miswan (2014) jaringan kerjasama adalah suatu sistem hubungan antar satu organisasi dengan organisasi lainnya. Menurut Bardach (1994) jaringan kerjasama antar organisasi adalah serangkaian hubungan kerja yang dilakukan oleh dua pihak atau lebih yang memiliki potensial dalam pencapaian tujuan organisasi dengan cara saling berbagi informasi atau bertukar pikiran. Samboteng dan Kasmad (2014) menyatakan bahwa jaringan kerjasama antar organisasi memiliki suatu tujuan yang ingin dicapai secara bersama melalui kerjasama akibat adanya ketidakpastian memperoleh sumberdaya organisasi dan salah satu dari organisasi memiliki potensi pencapaian tujuan organisasi. 
Jaringan kerjasama antar organisasi pada sekolah dilakukan oleh kepala sekolah dengan pihak lain di luar sekolah sebagai bentuk upaya pengembangan, penataan, dan pengelolaan sekolah menjadi lebih baik. Beberapa organisasi yang bergerak dibidang industri memanfaatkan jaringan kerjasama dalam pemasaran produk, pemilihan konsumen dan lain sebagainya sesuai dengan tujuan (Creveling, et.all, 2006).

Sekolah sebagai organisasi yang memiliki tujuan melahirkan generasi muda yang memiliki karakter mulia perlu melakukan kerjasama dengan organisasi lain sebagai bentuk upaya pencapaian tujuan sekolah, Kerjasama yang dilakukan sekolah dengan pemanfaatan dan bentuk yang berbedabeda disebabkan oleh keterbatasan sumberdaya sekolah. Pemanfaatan kerjasama yang dilakukan dapat berupa pemanfaatan kerjasama internal dan eksternal. Pemanfaatan kerjasama internal yaitu manfaat kerjasama yang dilakukan dengan tenaga pendidik, peserta didik, tenaga kependidikan dan orangtua peserta didik (Suarno \&Miswan, 2014). Sedangkan pemanfaatan jaringan kerjasama eksetrnal adalah melakukan kerjasama dengan pihak lain.

Pemanfaatan berasal dari kata manfaat yang memiliki makna guna, nilai, faedah atau segala sesuatu yang berkenaan dengan hasil yang postif. Menurut kamus bahasa Indonesia pemanfaatan memilik makna sebagai proses, cara, dan perbuatan yang memanfaatkan sesuatu untuk sesuatu yang berguna. Sehingga pemanfaatan jaringan kerjasama adalah proses, cara, dan perbuatan memanfaatkan jaringan kerjasama dalam pencapaian tujuan organisasi.

Pemanfaatan kerjasama antar organisasi banyak dikaji oleh peneliti terdahulu berkenaan dengan manfaat kerjasama (Erlangga, 2018, Ahmadi \& Aisyah, 2017; Dardiri, 2016; Haryana, Budjang, \& Salim, 2016; Isman dkk, 2011) dan implementasi kerjasama (Fitriyah \& Rani, 2013; Mengacu pada uraian di atas dan penelitian yang telah dilakukan sebelumnya, maka fokus penelitian penulis saat berkenaan dengan pandangan seorang pemimpin perempuan, dalam hal ini kepala sekolah menengah atas berkenaan dengan pemanfaatan jaringan kerjasama dalam mencapai tujuan sekolah yang mereka pimpin, meliputi (1) dasar pertimbangan dalam pemilihan jaringan kerjasama antar organisasi oleh kepala sekolah, dan (2) bentuk-bentuk jaringan kerjasama antar organisasi.

\section{METODE}

Penelitian ini menggunakan pendekatan penelitian kualitatif karena penelitian ini bertujuan untuk mendeskripsikan pandangan pemimpin perempuan berkenaan dengan pemanfaatan jaringan kerjasama dalam pencapaian tujuan. Pengumpulan data penelitian dilakukan dengan cara melakukan observasi, wawancara, dan dokumen. Observasi yang dilakukan adalah observasi non-partisipan yaitu peneliti tidak terlibat secara langsung dalam kegiatan yang dilakukan. Observasi dilakukan dengan memberikan pertanyaan secara umum terkait kerjasama antar organisasi untuk mengetahaui pemahaman awal informan. Wawancara dilakukan terhadap kepala sekolah menengah atas perempuan di kota Jambi yang memiliki status sekolah negeri maupun swasta melalui jaringan telepon. Pemilihan informan dilakukan setelah mendata jumlah sekolah menengah atas umum negeri dan swasta di Kota Jambi, dan mendata gender kepala sekolah tingkat menegah atas umum di kota Jambi. Dokumentasi berkenaan dengan visi, misi, dan tujuan sekolah, data-data sarana prasarana, data sekolah dan data lain yang mendukung tercapainya tujuan penelitian yang telah ditetapkan.

Analisis data dilakukan dengan tiga cara yaitu mereduksi, menyajikan, dan menarik kesimpulan. Data yang telah dikumpulkan dilakukan pemilahan sesuai dengan tujuan penelitian, untuk kemudian disajikan dan ditarik kesimpulan sesuai dengan langkah-langkah dalam penelitian kualitatif. Lebih lanjut dilakukan keabsahan data dengan menggunakan teknik trianggulasi data.

\section{HASIL}

Berdasarkan data yang yang diperoleh melalui website dinas pendidikan dan kebudayaan provinsi Jambi tentang data jumlah sekolah menengah atas umum yang berstatus negeri dan swasta di Kota Jambi ditemui data jumlah sekolah menegah atas umum yang bukan kejuruan, madrasah, maupun Islam 
terpadu terdapat 13 sekolah menengah atas umum berstatus negeri dan 21 sekolah menengah atas umum berstatus swasta. 90\% kepala sekolah menengah atas umum di Kota Jambi memiliki jenis kelamin Lakilaki. Berikut uraian hasil penelitian yang penulis temui lapangan:

\section{Dasar Pertimbangan Pemilihan Jaringan Kerjasama}

Pemimpin perempuan di sekolah menengah atas umum Kota Jambi baik swasta maupun negeri dalam melaksanakan tugas dan fungsinya sebagai pimpinan memiliki tanggungjawab dalam mencapai tujuan sekolah melalui rencana kegiatan yang telah disusun berdasarkan kesepakatan bersama.

Jaringan kerjasama dalam pandangan kepala sekolah perempuan sekolah menegah atas umum di Kota Jambi merupakan hal yang penting dan perlu dilakukan oleh pimpinan sebagai salah satu cara dalam pencapaian tujuan. Sebagaimana yang diutarakan oleh $\mathrm{KS}^{1}$ dibawah ini: "saya pikir kerjasama dengan pihak lain diluar sekolah sangat penting dalam upaya meningkatkan kualitas sekolah, membantu sekolah untuk menjadi lebih baik dan tentunya sebagai lembaga pendidikan, kerjasama tidak bisa tidak harus dibangun dengan pihak manapun, asal sifatnya membangun sekolah kita".

Hal senada disampaikan oleh $\mathrm{KS}^{3}$, bahwa kerjasama antar organisasi merupakan salah satu agenda sekolah dalam mencapai tujuan sekolah, karena melalui kerjasama, sekolah dapat terbantu dalam memecahkan masalah yang dihadapi. Pernyataan ini didasarkan pada kenyataan bahwa tidak semua sekolah memiliki sumberdaya sekolah yang mumpuni dalam mencapai tujuan sekolah.

Kepala sekolah perempuan dalam memilih jaringan kerjasama memiliki kecenderungan yang sama berupa saling menguntungkan, memberikan manfaat dan komunikasi yang baik yaitu komunikasi dua arah. Hal ini dikemukakan oleh $\mathrm{KS}^{1}, \mathrm{KS}^{2}$, dan $\mathrm{KS}^{3}$ pada waktu dan tempat yang berbeda.

Hasil olah data yang dilakukan oleh peneliti menemukan bahwa pemilihan jaringan kerjasama antar organisasi yang dilakukan oleh kepala sekolah perempuan sekolah menengah atas umum Kota Jambi didasarkan pada beberapa hal berikut ini yaitu:

1. Kerbatasan sumberdaya sekolah;

Keterbatasan sumber daya sekolah meliputi ruang kelas, fasilitas labor, tenaga professional.

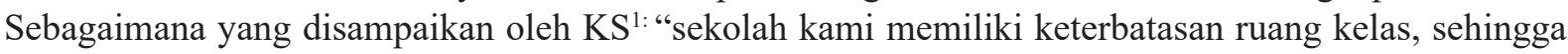
untuk menampung jumlah siswa di sekolah kami, kami meminjam ruang kelas SD, SMP yang berada dilingkungan dan yayasan yang sama dengan kami”.

Hal senada disampaikan oleh $\mathrm{KS}^{2}$, tanpa mendefinisikan keterbatasan sumberdaya sekolah yang dimiliki, pada dasarnya $\mathrm{KS}^{2}$ menyatakan jaringan kerjasama yang dibangun oleh mereka adalah dalam upaya memenuhi keterbatasam sumber daya sekolah.

\section{Kebutuhan peserta didik}

Kebutuhan peserta didik yang dimaksdu adalah hal-hal yang berkenaan dengan harapan terhadap output sekolah. Salah-satunya berupa karakter peserta didik yaitu peserta didik dapat memiliki sikap disiplin, beragama, bertanggungjawab, dan memiliki semangat untuk menuntut ilmu.

Terkait kebutuhan peserta didik tersebut maka perlu dilakukan kerjasama melalui jaringan kerjasama yang telah dipilih sebelumnya, berikut kutipan hasil wawancara dengan $\mathrm{KS}^{1}$ : " mengingat siswa kami kebanyakan berasal dari keluarga yang bermasalah, siswa kami memiliki karakter yang menurut kami perlu diperbaiki melalui kegiatan yang telah kami programkan melalui jaringannkerjasama yang kami miliki, yaitu dengan mengirimkan siswa kami untuk mengikuti kegiatan belajar dan mengajar di sebuah sekolah yang memiliki kemitraan dengan kami selama satu minggu".

\section{Kebutuhan informasi}

Berdasarkan hasil wawancara dengan kepala sekolah perempuan di sekolah menengah atas umum Kota Jambi, kebutuhan informasi merupakan faktor lain yang menjadi pertimbangan dalam memilih jaringan kerjasama, sebagai berikut: $\mathrm{KS}^{1}$ memberikan pernyataan bahwa : " kebutuhan akan informasi berkenaan dengan penyelenggaraan sekolah, baik berupa informasi kegiatan maupun pendanaan merupakan pertimbangan bagi kami dalam memilih jaringan kerjasama antar organisasi, oleh karena itu kami melakukan kerjasama dengan dinas pendidikan pastinya, dan ikut dalam forum kegiatan kepala sekolah". 
Selanjutnya, $\mathrm{KS}^{2}$ menegaskan: " Dalam penyelenggaraan sekolah tentunya, kami membutuhkan informasi yang akurat dan terkini untuk pengelolaan, pengembangan, dan penataan sekolah kami, terlibat aktif dalam forum kepala sekolah sekota Jambi dan pihak-pihak terkait seperti dinas pendidikan, forum musyawarah kepala sekolah, pengawas sekolah dan lainnya demi tercapainya tujuan yang kami tetapkan secara bersama."

Pernyataan yang sama disampaikan oleh $\mathrm{KS}^{3}$, dengan menekankan pada pentingnya informasi dalam hal apapun termasuk dalam penyelenggaraan sekolah, seperti di bawah ini: "penyelenggaraan sekolah dan informasi tidak bisa dipisahkan pastinya, oleh karena itu menjalin kerjasama dengan dinas pendidikan, dan pengawas serta kepala sekolah dari sekolah lain sangat penting".

\section{Bentuk-Bentuk Jaringan Kerjasama}

Hasil penelitian menunjukkan dalam jaringan kerjasama kepala sekolah perempuan sekolah menengah atas umum Kota Jambi lebih cenderung menjalin kerjasama dengan sekolah menengah atas sederajat dan lembaga lin yang memiliki kepedulian pada dunia pendidikan. Bentuk-bentuk jaringan kerjasama yang dilakukan berdasarkan hasil penelitian adalah berupa:

\section{Fasilitas}

Tidak semua sekolah yang dipimpin oleh kepals sekolah perempuan di sekolah menengah atas umum Kota Jambi memiliki fasilitas yang dapat menunjang pengelolaan sekolah. Fasilitas yang dimaksud berupa jumlah ruang kelas, laboratorium, dan sarana olahraga. Sekolah menengah atas umum negeri di Kota Jambi di bawah kepemimpinan kepala sekolah perempuan memiliki ruang kelas yang dapat menampung jumlah peserta didik, dan rata-rata memiliki fasilitas labor dan sarana olahraga tertentu seperti basket, sepak bola, tenis meja, dan tempat bermain badminton. Namun, seperti kolam renang siswa harus melakukannya di fasilitas umum yang tersedia di Kota Jambi.

Namun, bagi sekolah swasta yang dipimpin oleh kepala sekolah perempuan sekolah menengah atas umum di Kota Jambi, fasilitas yang sangat penting dalam melaksanakan kegiatan belajar mengajar yaitu ruang kelas sangat terbatas, tidak mencukupi dalam menampung jumlah peserta didik. Hal ini diutarakan oleh $\mathrm{KS}^{1}$ dengan pernyataan yang diuraikan berikut: "ruang kelas yang kami miliki tidak memiliki daya tampung yang cukup untuk seluruh jumlah peserta didik di sekolah kami, sehingga sebagai bentuk pemanfaatan jaringan kerjasama yang kami lakukan adalah dengan menggunakan ruang kelas sekolah dasar dan sekolah menengah pertama yang berada dalam satu yayasan dengan sekolah kami”.

\section{Sit in peserta didik}

Bentuk pemanfaatan jaringan kerjasama yang lain adalah sit in peserta didik pada sekolah lain yang sederajat, yang memiliki klaster lebih baik dari sekolah yang dipimpin oleh kepala sekolah umum perempuan di Kota Jambi. Sit in yang dilakukan berupa mengirim beberapa siswa untuk mengikuti kegiatan proses belajar mengajar di sekolah yang memiliki jaringan kerjasama dengan sekolah yang dipimpin oleh kepala sekolah perempuan Kota Jambi selama satu minggu sesuai dengan perjanjian yang dibuat.

Sit in yang dimaksud bertujuan memberikan wawasan baru bagi peserta didik dan diharapkan dapat mengubah perilaku dan cara pandang peserta didik serta memberikan pengalaman belajar bagi siswa. Berikut kutipan dengan $\mathrm{KS}^{1}$ : "Kami mengirimkan siswa kami untuk mengikuti proses belajar mengajar di sekolah Madrasah Insan Cendekia Jambi selama satu minggu, untuk memberikan pengalaman belajar bagi siswa kami dan memiliki perubahan dalam pola pikir dan perilaku".

Sedangkan bentuk sit in peserta didik yang dilakukan oleh kepala sekolah perempuan yang lain hanya melibatkan peserta didik dalam kegiatan-kegiatan yang memberikan pengayaan dalam motivasi dan semangat belajar siswa, seperti mengikutkan peserta didik pada kegiatan-kegiatan bersifat penguatan karakter. 


\section{PEMBAHASAN}

\section{Dasar Pertimbangan Pemilihan Jaringan Kerjasama}

Pemilihan jaringan kerjasama merupakan salah satu cara yang tepat dalam membantu organisasi baik organisasi sekolah maupun non-sekolah dalam mengembangkan, menata, dan mengelola sekolah agar tujuan yang telah ditetapkan terlaksana. Cerveling dkk (2006) menunjukkan pemilihan jaringan kerjasama antar organisasi non-sekolah dipilih sesuai dengan kebutuhan organisasi tersebut.

Hasil wawancara menunjukkan bahwa kepala sekolah perempuan dalam pemilihan jaringan kerjasama beradarkan atas tiga pertimbangan penting yaitu keterbatasan sumberdaya sekolah, kebutuhan peserta didik dan kebutuhan informasi. Berdasarkan hasil pengamatan dan penelusuran literature ketiga dasar pertimbangan dalam pemilihan kerjasama antar organisasi merupakan hal yang dapat memberikan manfaat dan keuntungan bagi sekolah dalam pencapaian tujuan sekolah (Bardach, 1994; Suarno \& Miswan, 2014)

Ketiga dasar pertimbangan dalam pemilihan jaringan kerjasama menurut kepala sekolah perempuan sekolah menengah atas Kota Jambi adalah hal mendasar dalam peencapaian tujuan sekolah. Keterbatasan sumberdaya sekolah mendorong kepala sekolah perempuan untuk menjalin kerjasama dengan pihak lain agar kegiatan yang telah ditetapkan dapat berjalan sebagaimana mestinya. Keterbatasan sumber daya sekolah meliputi ruang kelas, laboratorium, perpustakaan, sarana olahraga. Oleh karena itu, pemanfaatan jaringan kerjasama atas pertimbangan keterbatasan sumberdaya sekolah menjadi prioritas utama bagi kepala sekolah perempuan sekolah menengah atas Kota Jambi, seperti peminjaman ruang kelas, sarana olah raga, dan laboratorium.

Selanjutnya hasil penelitian menunjukkan bahwa dasar pertimbangan kedua dalam memilih jaringan kerjasama antar pihak lain adalah kebutuhan peserta didik karena peserta didik merupakan output sekolah yang nantinya akan menjadi input bagi level pendidikan lanjutan. Output yang diharapkan berupa outcome yang memiliki hasil guna dalam masyarakat. Oleh karena itu kepala sekolah perempuan sekolah menegah atas umum Kota Jambi dalam memilih jaringan kerjasama antar organisasi berdasarkan kebutuhan tersebut sebagai contoh ketika peserta didik perlu diperkuat karakternya, maka kepala sekolah menjalin kerjasama dengan sekolah yang memiliki siswa yang berkarakter, seperti bekerjasama dengan Madrasah aliyah Insan Cendekia Jambi.

Terakhir, yang menjadi dasar pertimbangan dalam melakukan jaringan kerjasama adalah kebutuhan informasi. Kebutuhan informasi yang dimaksud adalah berkenaan dengan penyelenggaraan, penataan, dan pengelolaan sekolah baik berupa program kegiatan, pendanaan, maupun kegiatan lain. Update informasi sangat perlu menurut kepala sekolah perempuan di sekolah menengah atas umum Kota Jambi, karena kadangkala disebabkan oleh kesibukan akan tugas-tugas lain dan keterbatasan akses dalam mencari informasi membuat kepala sekolah perempuan mengah atas umum Kota Jambi melakukan kerjasama dengan organisasi yang memiliki akses cepat dalam penerimaan informasi, seperti dinas pendidikan, pengawas sekolah dan kepala sekolah dari sekolah lainnya.

Pemilihan jaringan kerjasama, menurut kepala sekolah perempuan sekolah menengah atas Kota Jambi didasarkan pada ketiga pertimbangan di atas untuk mencapai tujuan sekolah.

\section{Bentuk-Bentuk Jaringan Kerjasama}

Bentuk jaringan kerjasama yang dimaksud adalah kerjasama yang dilakukan dalam kegiatan yang berkenaan dengan persoalan utama yang dihadapi oleh sekolah agar tujuan sekolah tercapai secara efektif dan efisien. Bentuk kerjasama dapat berupa kegiatan dan fasilitas karena adanya ketidakpastian sumberdaya yang dimiliki oleh sekolah (Samboteng \& Kasmad, 2014).

Bentuk jaringan kerjasama tersebut dijalankan dengan sekolah lain yang setingkat dan yang tidak setingkat namun memiliki tujuan yang sama yaitu melahirkan output yang memiliki kompetensi sesuai dengan amanah undang-undang No. 20 tahun 2003 tentang sistem pendidikan nasional. Selain itu, bentuk jaringan kerjasama yang dimanfaatkan adalah menjalin kerjasama dengan lembaga yang memiliki kepedulian terhadap pendidikan baik pemerintah maupun non pemerintahan. 
Mengacu pada pemilihan jaringan kerjasama dan bentuk-bentuk jaringan kerjasama yang dilakukan oleh kepala sekolah perempuan di sekolah menegah atas umum Kota Jambi, maka pemanfaatan jaringan kerjasama didasarkan pada nilai guna dan manfaat yang diperoleh bagi sekolah yang mereka pimpin berdasarkan atas pertimbangan ketersediaan sumber daya, kebutuhan peserta didik, dan kebutuhan informasi. Sumarsono (2018) menyatakan, bahwa dalam rangka meningkatkan mutu pendidikan sekolah diperlukan pula jalinan kerjasama atau partisipasi orangtu. Partisipasi orangtua dalam meningkatkan mutu pendidikan berbentuk fisik dan non-fisik. Sedangkan bentuk kerjasama yang dilakukan dalam pemanfaatan jaringan kerjasama adalah fasilitas seperti ruang kelas, ruang labor, sarana olahraga; sit in yaitu dimana siswa dari sekolah yang dipimpin oleh kepala sekolah perempuan ditempatkan di sekolah yang menjadi mitra selama satu minggu untuk mengikuti kegiatan belajar mengajar di sekolah yang menjadi jaringan kerjasama.

Sehingga pemanfaatan jaringan kerjasama bagi kepala sekolah perempuan di sekolah menegah atas umum Kota Jambi lebih banyak pada organisasi sejenis yang bergerak dalam bidang pendidikan.

\section{SIMPULAN DAN SARAN}

\section{Kesimpulan}

Berdasarkan hasil dan pembahasan yang telah diuraikankan, dapat disimpulkan bahwa pemanfaatan jaringan kerjasama antar organisasi dalam pandangan kepala sekolah menengah atas umum kota Jambi yang bergender perempuan sebagai bentuk upaya pencapaian tujuan sekolah dilakukan melalui pemilihan jaringan kerjasama yang dapat memberikan keuntungan, manfaat, dan komunikasi yang baik. Adapun dasar pertimbangan dalam melakukan kerjasama adalah ketersediaan sumberdaya sekolah, kebutuhan peserta didik, dan kebutuhan informasi. Sedangkan bentuk kerjasama dilakukan berupa penggunaan fasilitas dan sit in serta kerjasama lebih didominasi dengan lembaga pendidikan yang sederajat maupun tidak sederajat dan pihak lain yang fokus pada pendidikan.

\section{Saran}

Saran yang dikemukakan dalam penelitian ini adalah untuk lebih lanjut dilakukan kajian pada lokus yang lebih luas dan sudut pandang lebih dalam terkait pemanfaatan jaringan kerjasama dari aspek strategi dan prinsip dan dilakukan perbandingan dalam pemanfaatan jaringan kerjasama antara kepala sekolah perempuan dan kepala sekolah laki-laki.

\section{DAFTAR RUJUKAN}

Achmadi, S., \& Aisyah, A. 2017. Manfaat kerjasama dalam kelompok saat bermain sluncuran bagi anak usia dini. iJournal of early childhood and inclusive education, Vol 1(1).

Adler, N. J. 1996. Global women political leaders: An invisible history nd increasingly important future. Ledership Quarterly, Vol. 7. 133-161.

Alice, E., \& Mary, C. J. S. 2002. The leadership styles of women and men. Journal of social issues.

Bardach, E. 1994. Can Network theory illuminate interagency collaboration. Diakses dari https://www.hsg. harvard.edu/chg/dgworkshop/bardach.pdfpada tanggal 20 September 2020.

Creveling, M.C., Hambleton, L., \& McCarty, B. 2006. Six sigma for marketing process: An overview for marketing executives, leaders and managers. New York: Prentice Hall.

Dardiri, A. 2016. Optimalisasi kerjasama praktik kerja industry untuk meningkatkan citra sekolah dan daya saing lulusan SMK. Journal pendidikan dan pembelajaran, Vol 22 (2).

Erlangga, A.B.S. 2018. Kerjasama antar instansi pemerintah dalam penyalahgunaan narkoba pada kalangan pelajar di Kota Batu (Studi pada BNN Kota Batu dan Dinas Pendidikan Kota Batu. Thesis Universitas Brawijaya.

Fitriyah, H.R., \& Rani F. 2013. Implementasi kerjasama sister city kasus sister city Bandung-Braunschweig (Tahun 200-201). Journal transnasional, Vol 5(1).

Gipson, N. A., \& Pfaff, L. D., Mendelson, B. D., Catennanci, T. L., \& Burke, W. W. 2017. Women and leadership: Selection, development, leadership style and performance. The journal of applied behavioral science. 
Gupta, K. V., \& Bhawe, M. N. 2007. The influences of proactive personality and stereotype threat on women's entrepreneurial intentions. Journal of leadership \& Organizational Studies, Vol. 13, Issue 4.

Haryana, I., Budjang, G., \& Salim, I. 2016. Analisis kerjasama antar siswa kelas XII IIS 2 Muhammadiyah 1 Pontinak. Journal pendidikan dan pembelajaran khatulistiwa, Vol 5 (06).

Higgs, M. 2003. How can we make sense of leadership in the $21^{\text {st }}$ century?, Leadership organization development journal, Vol, 24, No.5 273-284.

Hicks, G. Herbert., \& Gullet, R. C. 1995. Organization: Theory and Behavior, Terj. Kartasapoetra. Jakarta: Bumi Aksara.

Hoyt, L. C., \& Murphy, E. S. 2016. Managing to clear the air: Streotype threat, women, and leadership. The leadership quarterly, Vol 27, Issue 3.

Knowles, G. 2011. Quality management. Diakses dari http://www.bookboon.com pada tanggal 12 Juni 2019.

Lipman, B. J. 1992. Connective leadership: Female leadership style in $21^{\text {st }}$ century workplace. Sociological perspective, Vol 35, No. 1, 183-203.

Mendelberg, T., \& Karpowhz, F. C. 2016. Women's authority in Political decision making groups. The leadership quarterly, Vol 27, Issue 3, 487-503.

Sheikh, A.M. 2010. Understanding educational management: A handbook for teachers and taught.

Samboteng, L., \& Kasmad, R. 2014. Sistem informasi organisasi berbasis jaringan dalam penentuan strategi. Jurnal Borneo Administrator, Vol 10, No. 2.

Suarno, W., \& Miswan. 2014. Konsep dasar jaringan kerjasama perpustakaan dan informasi. Jakarta: Universitas Terbuka.

Sumarsono, R.B., Imron, A. Wiyono, B.B., \& Arifin, I. 2016. Parents' Participation in Improving the Quality of Elementary School in the City of Malang, East Java, Indonesia. International Education Studies, v9 n10 p256-262. https://eric.ed.gov/?id=EJ1115999

Sumarsono, R. B. 2018. Upaya Mewujudkan Mutu Pendidikan Melalui Partisipasi Orangtua Siswa. Jurnal Ilmu Pendidikan. Volume 24. Nomor 2. http://journal2.um.ac.id/index.php/jip/article/view/9222

Werhane, H.P., \& Morland, P.M. 2011. Leadership, gender, and organization . London: Springer.

Yulk, G. 2010. Leadership in organization. New York: Pearson.

Undang-Undang No. 20 Tahun 2003 tentang Sistem Pendidikan Nasional. 